\title{
Archeologiczno-architektoniczne badania nowożytnego łącznika pomiędzy kościołem św. Jakuba w Toruniu a klasztorem benedyktynek w 2013 roku
}

Jakub Rychlik

Toruń

\section{Stan badań}

Badania archeologiczno-architektoniczne przy kościele św. Jakuba w Toruniu były prowadzone w latach 2008-2015 (z przerwami w roku 2009 i 2014) pod kierunkiem dr hab. Krystyny Sulkowskiej-Tuszyńskiej, prof. UMK ${ }^{1}$. Ich celem było m.in. wszechstronne rozpoznanie terenu wokół kościoła i dawnego klasztoru cysterek-benedyktynek, sprawdzenie istnienia $\mathrm{w}$ tym miejscu wcześniejszej świątyni (przed 1309 r.) i innych zabudowań oraz rozpoznanie fundamentów budowli. Dzięki badaniom możliwe stało się poszerzenie stanu wiedzy na temat kultury mieszczan Nowego Miasta Torunia, na podstawie m.in. znalezisk pochodzących z warstw cmentarnych, obejmujących okres od średniowiecza do początków XIX w. Wykopaliska z lat 2008-2015 umożliwiły również powstanie wielu prac naukowych o tematyce archeologicznej, dotyczących kościoła i klasztoru cysterek-benedyktynek. Autorką większości z nich jest Krystyna Sulkowska-Tuszyńska, będąca kierownikiem wspomnianych wyżej badań ${ }^{2}$. Informacje na temat badań

\footnotetext{
${ }^{1}$ Zorganizowano je w ramach praktyk dla studentów Instytutu Archeologii UMK.

${ }^{2}$ K. Sulkowska-Tuszyńska, Apud Terram, Ante Ecclesiam. Niezapisane karty historii kościoła i parafii św. Jakuba w Toruniu, Pomorania Antiqua, t. XXIII, red. H. Paner, Gdańsk 2010; taż, Kamienna misa chrzcielna odkryta przy kościele św. Jakuba w Toruniu, Slavia Antiqua, t. LIII, red. Z. Hilczer-Kurnatowska, Poznań 2012; taż, Primum
} 
przy kościele znalazły się również w wydawnictwach XVII i XVIII Sesji Pomorzoznawczej w dwóch artykułach autorstwa Krystyny Sulkowskiej-Tuszyńskiej i Anny Cichej ${ }^{3}$. Pojawiły się też inne prace na ten temat ${ }^{4}$. Wiele nowych danych dotyczących kościoła i klasztoru wniosły prace Anny Cichej ${ }^{5}$. Na podstawie badań archeologicznych przy kościele św. Jakuba powstało także łącznie siedemnaście prac licencjackich i magisterskich (maszynopisy w Instytucie Archeologii UMK).

non nocere! O archeologicznych badaniach wokót kościoła św. Jakuba, [w:] Stare $i$ nowe dziedzictwo Torunia. Studia i materialy $z$ dziedzictwa kulturowego Torunia i regionu, t. 1, red. J. Raczkowski, Torun 2013; taż, Prezbiterium kościoła św. Jakuba po badaniach archeologiczno-architektonicznych. Nowa historia Nowego Miasta Torunia?, [w:] Nowe Miasto Toruń. 750 lat od lokacji, red. K. Mikulski, P. Oliński, W. Rozynkowski, Torun 2014.

${ }^{3}$ K. Sulkowska-Tuszyńska, A. Cicha, Badania archeologiczno-architektoniczne przy kościele św. Jakuba Apostoła w Toruniu (sezon 2008), XVII Sesja Pomorzoznawcza, red. H. Paner, M. Fudziński, Gdańsk 2013; tychże, Badania archeologiczno-architektoniczne przy kościele św. Jakuba Apostoła w Toruniu (sezon 2010), XVIII Sesja Pomorzoznawcza, red. E. Fudzińska, Gdańsk 2013.

${ }^{4}$ K. Sulkowska-Tuszyńska, A. Cicha, Dawny klasztor przy kościele św. Jakuba w Toruniu i jego otoczenie $w$ świetle badań archeologicznych z lat 2008-2009, Rocznik Toruński, t. 37, 2010; K. Sulkowska-Tuszyńska, M. Wiewióra, Metodyka badań archeologiczno-architektonicznych $w$ procesie ksztatcenia $w$ toruńskim Instytucie Archeologii. Historia i praktyka, [w:] Badania architektoniczne. Historia i perspektywy rozwoju, red. M. Arszyński, M. Prarat, U. Schaaf, B. Zimnowoda-Krajewska, Toruń 2015

${ }^{5}$ A. Cicha, Klasztor cysterek-benedyktynek przy kościele św. Jakuba w Toruniu $w$ świetle źródet ikonograficznych i archeologicznych, [w:] Dzieje i skarby kościoła świętojakubskiego w Toruniu, red. K. Kluczwajd, Torun 2010; taż, Niełatwe odkrywanie klasztoru toruńskich cysterek-benedyktynek, czyli o badaniach archeologicznoarchitektonicznych z lat 2008-2010, [w:] Forum Scientiae Cisterciense. Przyszłość badań nad historia i kultura cysterska w Polsce, red. E. Łużyniecka, A. Galar, Wrocław 2011; taż, „Wieniec (...) zostal dla mnie upleciony”. Pochówki w wiankach $z$ cmentarza przy kościele św. Jakuba w Toruniu, [w:] Obraz struktury spotecznej $w$ świetle źródet archeologicznych $w$ pradziejach i średniowieczu, red. M. Rybicka, Rzeszów 2011; taż, Domy zakonne zamykaja się, maja ścisła klauzurę (...), aby siostry (...) przyzwoitość zakonna jak najprzykładniej zachowywaty - tzw. łacznik nowożytny między klasztorem a kościołem św. Jakuba Apostoła w świetle badań archeologicznoarchitektonicznych, [w:] Stare i nowe dziedzictwo Torunia, t. 1; taż, „Wy, którzy przechodzicie obok nas, wnet będziecie tym, czym my jesteśmy" - kwatera zachodnia cmentarza przy nowomiejskim kościele św. Jakuba, [w:] Nowe Miasto Torun. 750 lat od lokacji. 
W ramach badań wykopaliskowych archeolodzy próbowali zweryfikować zmiany dokonane w planie budowy w trakcie jej trwania, odnaleźć relikty dawnego budownictwa oraz potwierdzić istnienie i sprawdzić przebieg tzw. łącznika klasztornego. To ostatnie zamierzenie zostało zrealizowane w 2013 r. $^{6}$, podczas piątego sezonu badań, dzięki założeniu wykopu oznaczonego jako $\mathrm{W}-12 / 13^{7}$, w miejscu przebiegu domniemanego korytarza łączącego w okresie nowożytnym kościół i pobliski klasztor cysterek-benedyktynek ${ }^{8}$. Na podstawie źródeł pisanych i ikonograficznych możliwe było ustalenie, że konstrukcja ta powstała krótko po 1667 r., kiedy to siostry zakonne odzyskały z rąk protestantów kościół św. Jakuba i budynki klasztorne'. W związku z tym konieczna stała się szybka budowa korytarza, który pozwalałby mniszkom przechodzić do świątyni bez opuszczania klauzury.

Wykop W-12/13 znajdował się po południowej stronie kościoła, pomiędzy świątynią a budynkiem dawnego klasztoru. Najważniejsze odkrycie, jakiego w nim dokonano, stanowią fundamenty wspomnianego wcześniej łącznika, zburzonego w latach 30. XIX w. po kasacie zgromadzenia benedyktynek. Po odsłonięciu jego ceglanej posadzki i ściany wschodniej wykop został poszerzony w celu odkrycia muru zachodniego. Korytarz miał szerokość ponad 4 metry i nieco łukowaty przebieg. Budowla wychodziła $\mathrm{z}$ kościoła $\mathrm{w}$ kierunku południowowschodnim. Po kilku metrach zmieniała swój przebieg na południowy zachód, a dalej zapewne łączyła się z nieistniejącą obecnie zabudową, która przylegała do wschodniej ściany głównego budynku klasztornego (ryc. 1). Obok wykopu 12 pod koniec prac został wykonany mały wykop sondażowy, mający potwierdzić dalszy przebieg korytarza ${ }^{10}$.

\footnotetext{
${ }^{6} \mathrm{~W}$ poprzednich sezonach $(2008,2011$ i 2012) natrafiono trzykrotnie na ślady ścian łącznika (zob. A. Cicha, Domy zakonne zamykaja się).

${ }^{7} \mathrm{~W}$ tym samym sezonie założono jeszcze dwa inne wykopy: W-13/13 po północnej stronie kościoła przy prezbiterium i W-14/13 przy południowo-zachodnim narożniku kościoła.

${ }^{8}$ Obecnie budynek Muzeum Okręgowego w Toruniu.

${ }^{9}$ L. Krantz-Domasłowska, J. Domasłowski, Kościół świętego Jakuba w Toruniu, Toruń 2001, s. 17-18.

${ }^{10}$ Informacje na podstawie sprawozdania z badań w 2013 r. zob. K. SulkowskaTuszyńska, Sprawozdanie z badań archeologiczno-architektonicznych przy kościele św. Jakuba w 2013 roku.
} 


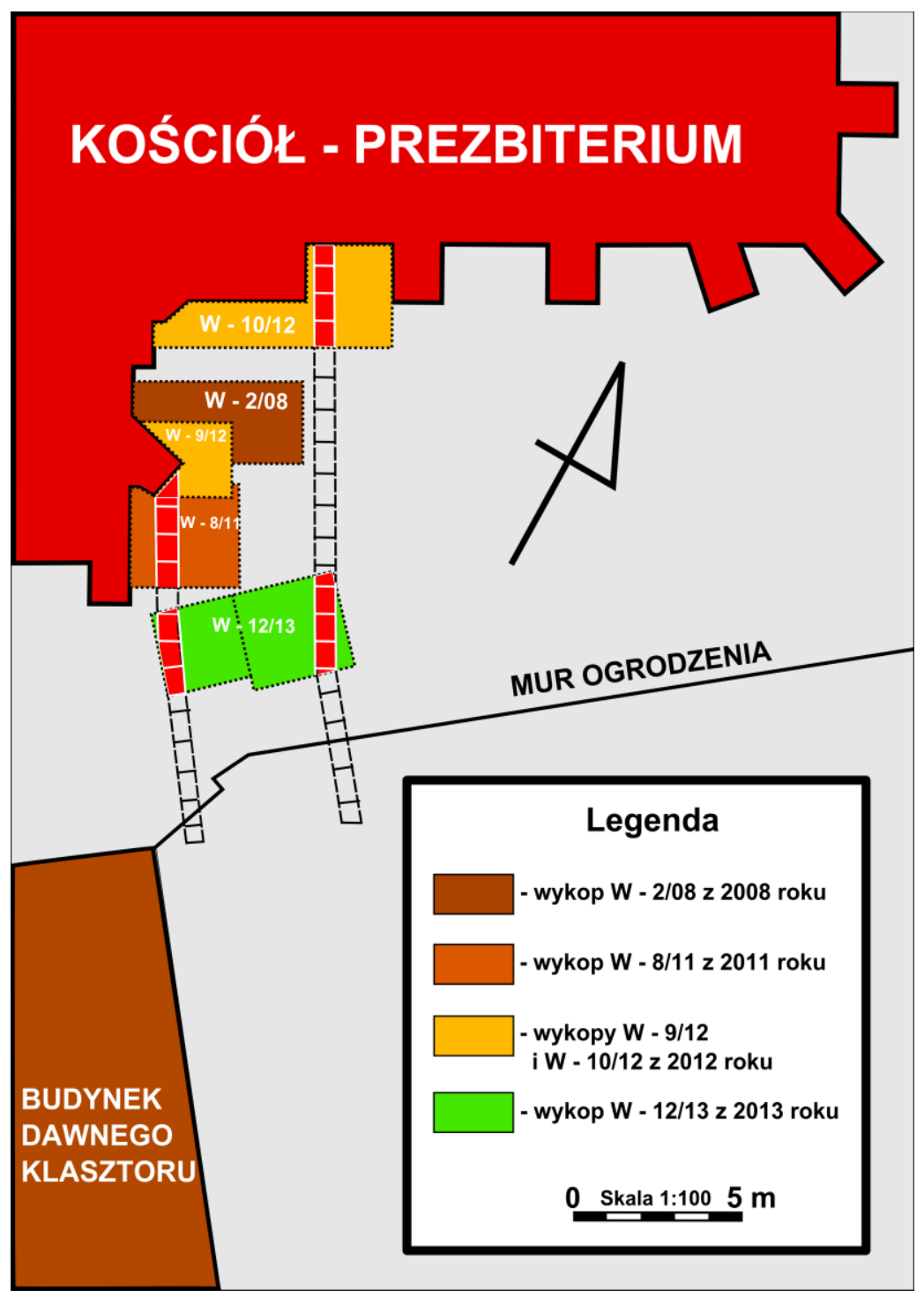

Ryc. 1 Torun - kościół św. Jakuba. Rekonstrukcja przebiegu łącznika klasztornego na podstawie odkryć z wykopu W-12/13 oraz wykopów założonych w latach 2008-2012 (rys. J. Rychlik) 


\section{Wyniki badań archeologiczno-architektonicznych}

Ze względu na położenie stanowiska archeologicznego przy kościele św. Jakuba na terenie Nowego Miasta Torunia oraz rozbudowany układ zespołów warstw wyznaczenie wyraźnej stratygrafii w tym miejscu jest trudnym zadaniem. Przyczyną takiego stanu rzeczy jest silne przemieszanie warstw, spowodowane m.in. istnieniem cmentarza przykościelnego, użytkowanego aż do około 1839 r., licznymi akcjami budowlanymi wokół kościoła ${ }^{11}$, wielokrotnymi pożarami świątyni i jej odbudowami, wreszcie budową korytarza między klasztorem a kościołem, rozpoczętą po 1667 r., kiedy na to miejsce powróciły cysterkibenedyktynki.

W trakcie badań archeologiczno-architektonicznych we wszystkich sezonach zastosowano metodę eksploracji warstwami mechanicznymi o średniej miąższości około $15 \mathrm{~cm}$. Po wyeksplorowaniu 10 warstwy mechanicznej prace $\mathrm{w}$ podstawowej części wykopu (prostokąt o wymiarach $3 \times 2,8 \mathrm{~m}$ ) zostały tymczasowo wstrzymane. Następnie wykop został poszerzony $\mathrm{w}$ stronę zachodnią o około 2,5 m. Część poszerzona została oznaczona umownie literą R. Była ona eksplorowana do momentu zrównania jej powierzchni z pozostałą partią wykopu, tj. do usunięcia 10 warstwy mechanicznej. Po zdjęciu tego poziomu rozpoczęto eksplorację całej powierzchni wykopu. W 2013 r., podczas eksploracji w wykopie W-12/13 wyróżniono 17 warstw (ryc. 2), pogrupowanych w cztery zespoły. Pierwszy obejmuje warstwy 1-3, stanowiące współczesny, najnowszy poziom użytkowy, powstały po remontach i przebudowach kościoła w XIX i na przełomie XIX i XX w. Pierwszą warstwę mechaniczną stanowił jasnożółty, drobnoziarnisty piasek, będący podsypką pod współczesne płyty chodnikowe i bruk. Na tym poziomie nie odkryto żadnych zabytków. Kolejna, 2 warstwa mechaniczna to ciemnoszarobrunatna, spiaszczona próchnica z pojedynczymi przeplamieniami żółtego piasku z podsypki i drobnymi fragmentami gruzu ceglanego i zaprawy. Największa koncentracja gruzu wystąpiła przy południowym profilu wykopu. Podczas eksploracji tej warstwy odkryto fragmenty szkła, naczyń ceramicznych i kafli oraz przedmiotów

\footnotetext{
${ }^{11}$ Między XIV a XVI w. do jego bryły dostawiono kaplice.
} 


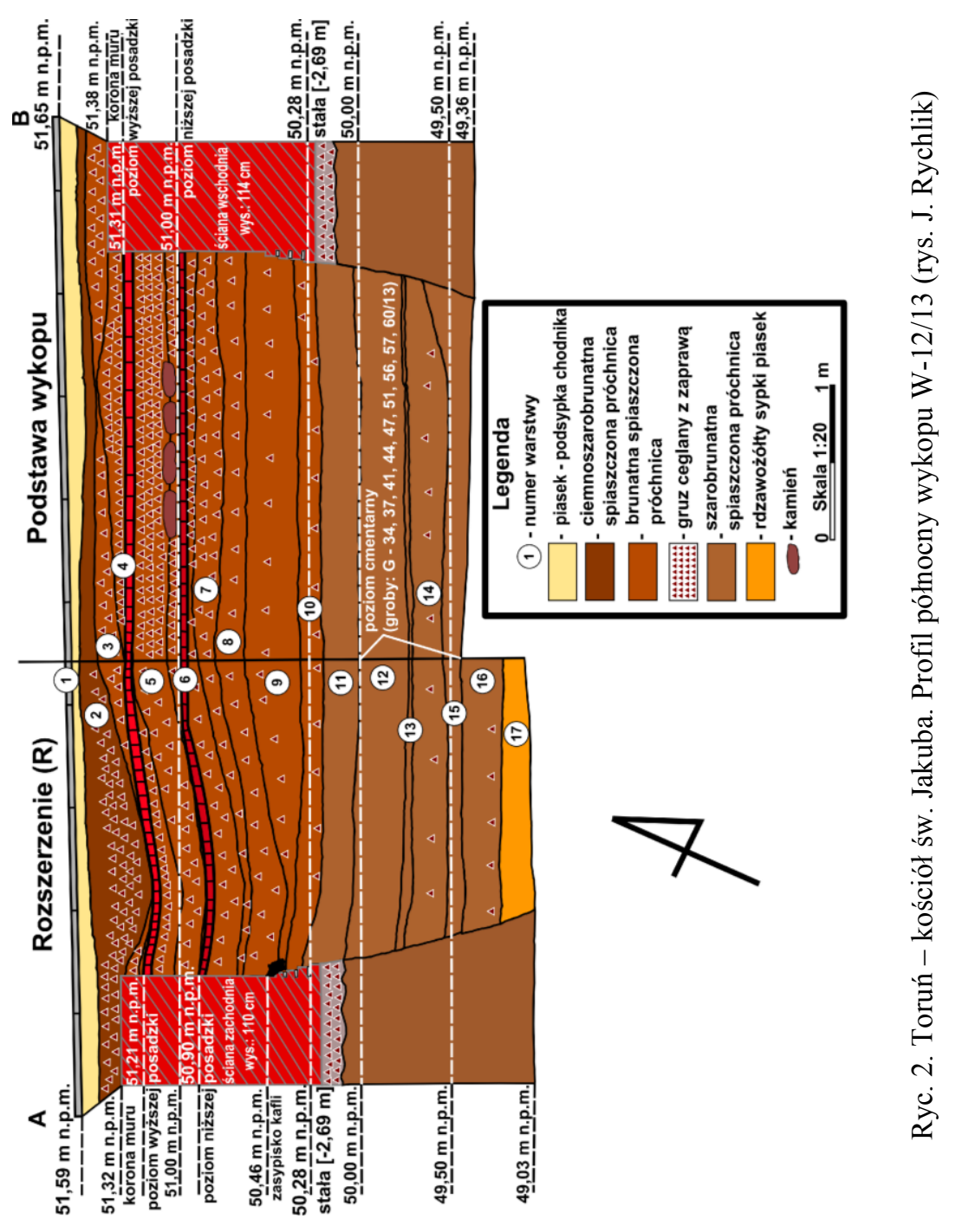


metalowych. Odsłonięto w niej także koronę zachodniej ściany łącznika. Do zespołu pierwszego należała też 3 warstwa mechaniczna, składająca się z brunatnej, spiaszczonej próchnicy z dużymi ilościami gruzu ceglanego i zaprawy, silnie skoncentrowanymi w północnej i południowej części wykopu. We wschodniej części wystąpiły niewielkie ilości węgla drzewnego. Znaleziono tu fragmenty ceramiki naczyniowej i budowlanej, kawałki szkła okiennego i naczyniowego oraz kości zwierzęce i przedmioty metalowe. Odkryto w niej również koronę wschodniego muru łącznika.

W trakcie eksploracji już w pierwszych warstwach wykopu W-12/13 zauważalne stały się relikty łącznika klasztornego zburzonego w XIX w. Początkowo miały one postać luźnego, ceglanego gruzu wraz z koncentracjami zaprawy murarskiej na całej powierzchni wykopu, a z czasem zaznaczyły się jako czytelne pozostałości fundamentu korytarza.

Pierwszy zespół jednostek stratyfikacyjnych w obrębie wykopu W12/13 uformował się po rozebraniu łącznika klasztornego w 1 . połowie XIX w. i kolejnych przebudowach i remontach kościoła wykonywanych do XX w. Położony był on na wysokości od 51,65 m n.p.m. do 51,22 m n.p.m.

W skład drugiego zespołu jednostek weszły warstwy 4-6. Były to: piaszczysta, brunatna próchnica, zawierająca gruz ceglany (w stropie warstwy 4) i dwa poziomy posadzki nowożytnego korytarza. Górna posadzka, znajdująca się na wysokości 51,21-51,31 m n.p.m., była dobrze zachowana we wschodniej części wykopu. Nie udało się bliżej określić czasu jej ułożenia, choć przypuszcza się, że miało to miejsce w XVIII w. Posadzka dolna położona została na wysokości 50,9051,00 m n.p.m. Była bardzo zniszczona; zbudowano ją niedługo po wymurowaniu łącznika klasztornego, a więc między trzecią a czwartą ćwiercią XVII w. W narożniku północno-wschodnim widoczna stała się jedna ze ścian łącznika (wschodnia), pokryta zaprawą murarską. Warstwę 4 tworzyła ciemnoszarobrunatna, spiaszczona próchnica $\mathrm{z}$ dużymi ilościami gruzu ceglanego, silnie skoncentrowanego w północnej i południowej części wykopu (w części centralnej zauważono jego mniejsze ilości, co jest oznaką istnienia w tym miejscu wnętrza korytarza). W części wschodniej i zachodniej wystąpiło dużo luźnego gruzu 
i zaprawy. $Z$ warstwy zebrano ceramikę naczyniową i budowlaną (płytka posadzkowa), kości ludzkie i zwierzęce oraz fragmenty szkła i metalu. Strop 5 warstwy mechanicznej stanowiła odkryta wcześniej ściana łącznika $\mathrm{z}$ licznymi śladami zaprawy. Poza tym warstwa 5 zawierała koncentracje zaprawy $\mathrm{z}$ drobinami gruzu ceglanego w południowo-wschodnim i południowo-zachodnim narożniku wykopu. Wydobyty na tym poziomie materiał stanowią fragmenty ceramiki, szkła i przedmioty metalowe. W trakcie eksploracji 6 warstwy mechanicznej usunięto relikty posadzki z części centralnej i zachodniej wykopu, nie naruszając pozostałości muru. Opisywana warstwa składała się ze spiaszczonej próchnicy z dużymi ilościami gruzu ceglanego i zaprawy. W północnej części eksplorowanej powierzchni zauważono węgielki drzewne, a w południowej soczewkę gliny. W 6 warstwie zachował się także bruk kamienny - znajdował się on w południowym profilu wykopu, blisko zabudowań klasztornych, na wysokości 51,00 m n.p.m. Do wydobytych $\mathrm{z}$ tego miejsca materiałów należą przedmioty metalowe ( $\mathrm{w}$ tym jeden brązowy), fragmenty ceramiki, szkła i relikty wianka grobowego.

Po usunięciu gruzu zalegającego w 3 warstwie mechanicznej, w południowej partii wykopu, na wysokości $51,28 \mathrm{~m} \mathrm{n.p.m.} \mathrm{odsłonięto}$ nowożytną posadzkę łącznika (ryc. 3). Jej relikty miały postać grubej warstwy potłuczonych cegieł i zaprawy murarskiej. Na dalszym etapie eksploracji, w południowej partii stropu warstwy 4 uwidoczniła się większa powierzchnia bardzo zniszczonej, ceglanej podłogi korytarza. W trakcie usuwania czwartego poziomu stratygraficznego odsłonięto fragment wschodniej ściany łącznika, od wysokości 51,38 m n.p.m. Cegły, z których ją zbudowano, miały inny układ niż posadzka, ułożona ukośnie w tzw. ,jodełkę”. W zachodniej części wykopu (wys. 51,32 $\mathrm{m}$ n.p.m.) odsłonięto zbudowaną $\mathrm{w}$ ten sam sposób ścianę zachodnią łącznika. Podobnie jak w przypadku pierwszego muru pozostawiono ją, prowadząc dalszą eksplorację i usuwając posadzkę, położoną na wysokości od 51,15 m n.p.m. do 51,23 m n.p.m. Podczas jej zdejmowania odnaleziono ornamentowaną płytkę posadzkową o wymiarach: $24 \times 22 \times 4,5 \mathrm{~cm}$. W południowo-wschodnim i południowo-zachodnim narożniku wykopu występowała koncentracja zaprawy z drobinami gruzu. W części środkowej podłogę niszczyły korzenie drzew. Podczas usu- 


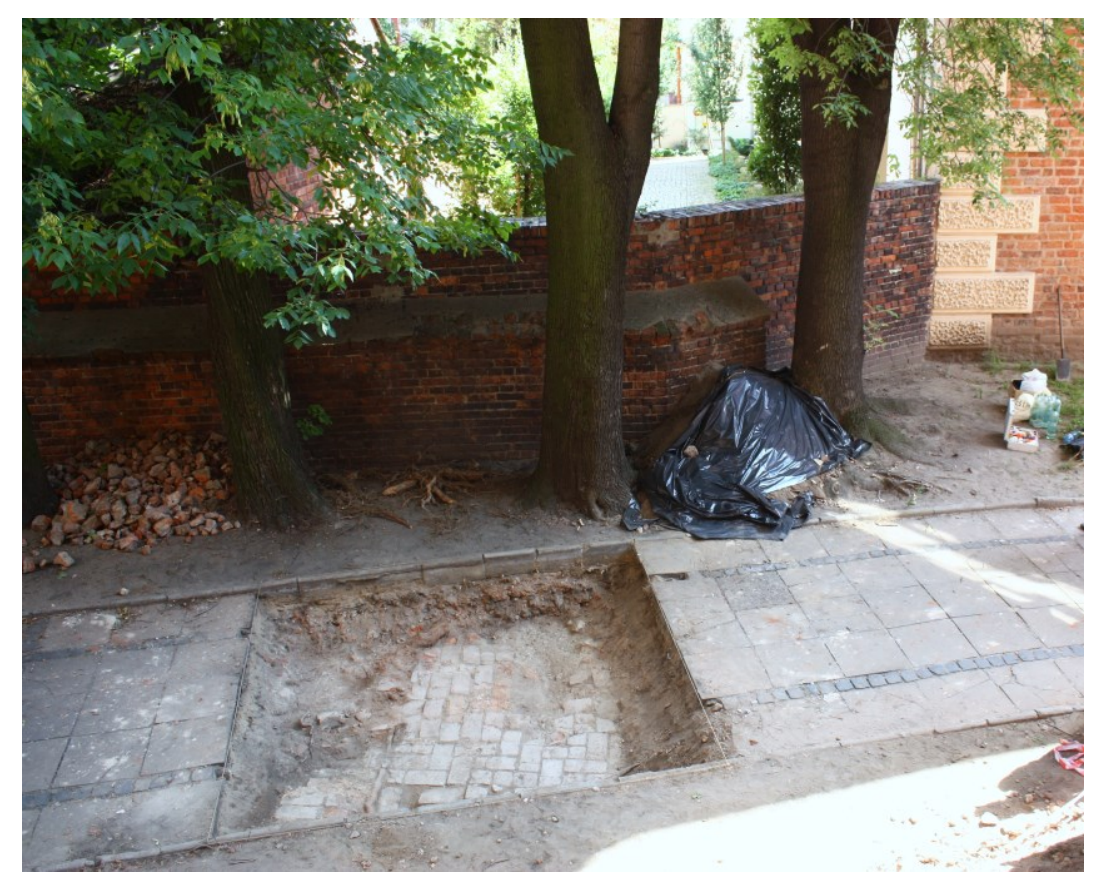

Ryc. 3. Torun - kościół św. Jakuba. Odsłonięta w wykopie W-12/13 posadzka łącznika (fot. A. Cicha)

wania 5 warstwy mechanicznej do analizy pobrane zostały trzy cegły o następujących wymiarach: 1) 30 x 14 x 7,5 cm;2) $28,5 \times 14$ x $8 \mathrm{~cm}$; 3) $28,5 \times 13,5 \times 8 \mathrm{~cm}$. Cegły posadzkowe zdejmowano od strony zachodniej przy jednoczesnym pozostawieniu reliktów ściany odkrytej w partii wschodniej wykopu. Dalsza eksploracja doprowadziła do odsłonięcia dużych otoczaków, umieszczonych wzdłuż południowego profilu. Stanowiły one pas kamieni o szerokości $26 \mathrm{~cm}$ i długości $100 \mathrm{~cm}$ na wysokości 51,00 m n.p.m. Pod podłogą łącznika znajdowały się niewielkie drobiny gruzu z zaprawą, które zalegały w 6 i 7 warstwie mechanicznej.

Drugi zespół nawarstwień powstał między około 3-4 ćwierci XVII w. a początkiem XIX w. Należy go łączyć z funkcjonowaniem tzw. łącz- 
nika klasztornego i położeniem w jego wnętrzu dwóch posadzek. Zalegał on na wysokości od 51,22 m n.p.m. do 50,68 m n.p.m.

Kolejny, trzeci zespół jednostek stratyfikacyjnych obejmują warstwy mechaniczne 7-11, składające się z próchnicy przemieszanej z gruzem i spalenizną, miejscami zawierające spieki szklane. Ślady węgielków drzewnych świadczą o pożarze z około 2. połowy XVII w. Wymienione warstwy zostały przecięte przez wkopy fundamentowe pod budowę łącznika. Siódma warstwa mechaniczna zawierała brunatną, spiaszczoną próchnicę $\mathrm{z}$ gruzem ceglanym i zaprawą. Odkryto w niej przedmioty metalowe, ceramikę naczyniową i budowlaną, fragmenty kafli ornamentowanych, kość zwierzęcą (ząb) i fragmenty szkła. Kolejna, 8 warstwa mechaniczna różniła się od poprzedniej obecnością większej ilości zaprawy, a zawierała fragmenty ceramiki, szkła i przedmiot metalowy. Znaleziono w niej również szeląg Gustawa Adolfa. Dziewiąty poziom stratygraficzny zbudowany był z brunatnej, spiaszczonej próchnicy z mniejszymi niż w poprzednich warstwach ilościami gruzu i zaprawy. W południowej części wykopu zostały zauważone niewielkie soczewki bladożółtej gliny. Warstwa zawierała fragmenty ceramiki naczyniowej i budowlanej, przedmioty metalowe (w tym szpilkę) i kości. W 8 i 9 poziomie stratygraficznym odkryto zasypisko z kafli ornamentowanych, które dołączono do inwentarza zabytków wydzielonych. Na granicy tych warstw położona była także pierwsza odsadzka muru zachodniego. W profilu odkrytej uprzednio wschodniej ściany łącznika odsłonięta została ludzka czaszka. Drobiny gruzu zmieszanego z zaprawą zaniknęły w 9 poziomie stratygraficznym. Jednocześnie w murze wschodnim łącznika ujawniono kolejne dwie czaszki. Oznacza to, że wykonany po $1667 \mathrm{r}$. wkop fundamentowy naruszył wcześniejsze pochówki z cmentarza przykościelnego. Mniej więcej w połowie warstwy 9 odsłonięta została pierwsza odsadzka muru wschodniego, a tuż pod nią kolejna. Następny, 10 poziom zawierał brunatną, spiaszczoną próchnicę, pojedyncze drobiny gruzu ceglanego i zaprawy, drobne węgielki drzewne i spieki szklane. Odkryto w nim kości ludzkie, ceramikę naczyniową i budowlaną (fragment kafla ornamentowanego) oraz przedmioty metalowe (w tym szpilkę). Na tym poziomie położone były także druga i trzecia odsadzka ściany zachodniej 
łącznika oraz trzecia i czwarta odsadzka ściany wschodniej ${ }^{12}$. Obie ściany miały po cztery poziomy ceglanych odsadzek (ryc. 2). Poniżej wysokości 50,28 m n.p.m. kończyła się wyraźnie czytelna partia fundamentu położona na warstwie kamieni. Jego grubość wahała się od 15 do $20 \mathrm{~cm}$.

Trzeci zespół jednostek uformował się przed rozpoczęciem akcji budowlanej łącznika i wiąże się zapewne z końcową fazą tzw. okresu protestanckiego, tzn. około 1. połowy XVII stulecia. Położony był on na wysokości od 50,68 m n.p.m. do 50,02 m n.p.m.

Czwarty zespół jednostek wyznacza poziom cmentarny, zamykający się w warstwach mechanicznych 12-16, złożonych z szarobrunatnej próchnicy, niekiedy zawierającej glinę, drobiny gruzu i otoczaki. W ich obrębie wyróżniono cztery poziomy grobów z dziewięcioma jednostkowymi jamami, bez wyposażenia i śladów trumien (groby o numerach: G-34, 37, 41, 44, 47, 51, 56, 57, 60/13). Zanim natrafiono na pierwszy grób, zdjęta została 11 warstwa mechaniczna, szarobrunatna, spiaszczona próchnica $\mathrm{z}$ pojedynczymi drobinami gruzu ceglanego, zawierająca fragmenty ceramiki, przedmioty metalowe, kości zwierzęce i dwie szpilki.

Najwyższy, czwarty poziom cmentarny obejmował grób oznaczony w inwentarzu jako G-34/13, odkryty w 12 warstwie mechanicznej. Składała się ona z szarobrunatnej, spiaszczonej próchnicy z drobnymi węgielkami drzewnymi i spiekami szklanymi. Zawierała fragmenty ceramiki, przedmioty metalowe, kości ludzkie i zwierzęce oraz wianek grobowy. Szkielet skierowany był twarzoczaszką na wschód, z rękami ułożonymi wzdłuż tułowia ${ }^{13}$. Pozostałości wkopu były nieczytelne, a w grobie nie znaleziono konstrukcji grobowej ani elementów wyposażenia. W warstwie 13 znajdowały się trzy jamy grobowe: G-37/13, G-41/13 i G-44/13. Poziom ten zawierał brunatnoszarą, spiaszczoną próchnicę, ceramikę (w tym fragment naczynia kamionkowego) i przedmioty metalowe. Grób 37 znajdował się we wschodniej partii wykopu, a szkielet częściowo zagłębiony był w jego wschodni profil, od pasa w dół. Po-

\footnotetext{
${ }^{12}$ Odpowiadającą jej czwartą odsadzkę odkryto także w murze zachodnim, w warstwie 11.

${ }^{13}$ Zachowały się kości kończyn dolnych i górnych, czaszka, kręgi, żebra, miednica i łopatki.
} 
chówek ułożono na osi wchód-zachód, z głową skierowaną na zachód, a twarzoczaszką w kierunku wschodnim. Czaszka była mocno zniszczona przez fundament łącznika klasztornego. Niemożliwe było ustalenie położenia kości rąk. Jako kolejny grób (G-41/13) wydzielone zostały szczątki innego osobnika, wyłaniające się z północnego profilu wykopu $^{14}$. Szkielet usytuowany był na osi wschód-zachód, twarzoczaszką na wschód. Na podstawie ułożenia kości promieniowej i dłoni można wnioskować, że zmarłego pochowano $\mathrm{z}$ rękami wyciągniętymi wzdłuż tułowia. Pozostałości innego pochówku z poziomu 13. oznaczono jako G-44/13 ${ }^{15}$. Zmarły ułożony został na osi wschód-zachód, twarzoczaszką na wschód. Niemożliwe było ustalenie pozycji rąk względem ciała. Wokół grobu nie odnaleziono śladów wkopu i wyposażenia. Zauważalne było natomiast cienkie, prostokątne w kształcie przebarwienie, interpretowane jako pozostałość trumny lub obstawy grobowej.

Najwięcej pochówków w wykopie W-12/13 odkryto w drugim poziomie cmentarnym, w którym zlokalizowano cztery groby: G-47/13, G-51/13, G-56/13 oraz G-57/13. Były one położone w 14 warstwie mechanicznej - szarobrunatnej, spiaszczonej próchnicy z drobinami gruzu ceglanego. Na tym poziomie znajdowały się także fragmenty ceramiki, przedmioty metalowe i kości. W grobie 47 pochowano kilkuletnie dziecko, co można wnioskować na podstawie niskiego wzrostu $(112 \mathrm{~cm})$. Jego szkielet spoczywał na osi wschód-zachód, z twarzoczaszką skierowaną na wschód. Ręce zmarłego złożono na miednicy. Szczątki kolejnego osobnika, wyłaniające się częściowo z północnego profilu wykopu, oznaczono jako grób $51^{16}$. Zmarły spoczywał na osi wschód-zachód, z twarzoczaszką skierowaną na wschód. Pochówek był częściowo znisz-

\footnotetext{
${ }^{14}$ Stanowiły je: kości kończyny dolnej - udowa, piszczelowa, strzałkowa, piętowa oraz kości kończyny górnej - promieniowa i kości dłoni.

${ }^{15}$ Zaliczono do nich kości odnalezione w południowo-wschodniej partii wykopu. $\mathrm{Z}$ jego południowego profilu wystawała lewa strona szkieletu: żebra, część miednicy, kość udowa, rzepka, kości ręki.

${ }^{16}$ Stanowiły je ułożone w porządku anatomicznym kości prawej nogi, miednicy, dolne partie kręgosłupa i kości prawej kończyny górnej. Kości stopy zagłębione były we wschodni profil wykopu.
} 
czony $^{17}$. Poniżej znajdowały się kolejne szczątki ludzkie (G-56/13), zachowane w postaci kości miednicy, kończyny dolnej i dolnych kręgów, ułożone w porządku anatomicznym. Orientacja szkieletu była identyczna jak w poprzednim przypadku. Przedostatni, 57 grób położony był $\mathrm{w}$ centralnej partii wykopu. Zawierał on szkielet dziecka, ułożony na osi wschód-zachód, z twarzoczaszką skierowaną na wschód i rękami wyprostowanymi wzdłuż tułowia. W najstarszej warstwie cmentarnej archeolodzy odkryli jeden grób, oznaczony jako G-60/13 (pozostawiono go na stanowisku). Położony był w 15 warstwie mechanicznej, zawierającej szarobrunatną, spiaszczoną próchnicę z nielicznymi kamieniami otoczakowymi i fragmentami ceramiki. Grób 60 leżał w północno-wschodniej części wykopu i był zachowany fragmentarycznie, orientowany na osi wschód-zachód. Niemożliwe było ustalenie ułożenia rąk względem tułowia. Żadnemu z odkrytych pochówków nie towarzyszyły ślady wkopu, konstrukcji grobowej ani wyposażenia ${ }^{18}$.

Przedostatnia, 16 warstwa zawierała we wschodniej części wykopu szarobrunatną, spiaszczoną próchnicę, a w części zachodniej szarobrunatną, spiaszczoną próchnicę przemieszaną z szarożółtą gliną. W warstwie występowały niewielkie ilości gruzu ceglanego, drobiny zaprawy i spalenizny. Do zabytków odkrytych na tym poziomie należą fragmenty ceramiki i przedmioty metalowe. Ze względu na pojawienie się zarysów kolejnych grobów w części wschodniej wykopu, eksploracją objęto jedynie jego zachodnią partię.

Opisany wyżej zespół jednostek kulturowych należy łączyć z funkcjonowaniem przykościelnego cmentarza $\mathrm{w}$ okresie średniowiecza do czasów nowożytnych (XIV-XVI/XVII w.?). Znajdował się on na głębokości od 50,02 m n.p.m. do 49,21 m n.p.m.

Ostatni zespół jednostek stratyfikacyjnych stanowiły dwie warstwy (17 i 18). 17 warstwa mechaniczna zawierała szarobrunatną, spiaszczoną próchnicę przemieszaną z szarożółtą gliną z pojedynczymi, luźnymi

\footnotetext{
${ }^{17}$ Nie odkryto lewych partii ciała, a żuchwa leżała obok ręki. Niemożliwe było ustalenie położenia rąk względem ciała.

${ }^{18}$ Przedstawiona powyżej numeracja grobów wynika z faktu, że podczas badań prowadzono jeden, wspólny dla wszystkich wykopów inwentarz. Na bieżąco gromadzono w nim informacje na temat odkrywanych pochówków, którym nadawano kolejne numery.
} 
otoczakami. W południowo-wschodnim narożniku części zachodniej wykopu występowała soczewka szarożółtego piasku i zaprawy. Z tej warstwy wydobyto nieliczne fragmenty ceramiki. Eksplorację zakończono po osiągnięciu stropu 18 warstwy mechanicznej. Na jego powierzchni przeważały: rdzawożółty, sypki piasek z przeplamieniami szarobrunatnej, spiaszczonej próchnicy, stanowiący w tym miejscu calec. W południowo-wschodnim narożniku wykopu nadal widoczna była soczewka szarożółtego piasku i zaprawy. Strop warstwy 18 znajdował się na wysokości 49,03 m n.p.m.

Ostatni poziom (17) eksplorowany był tylko w zachodniej części wykopu, w której ujawniono duże ilości kamieni i zaprawy. Mogły one stanowić podłoże fundamentu ściany zachodniej. Po zakończeniu eksploracji wykonano pomiary cegieł i obu murów łącznika oraz sporządzono dokumentację rysunkową i fotograficzną wszystkich profili, rzut płaski i plan sytuacyjny wykopu. W każdej ze ścian wykopu zmierzono po trzy cegły. Miały one wymiary: w murze zachodnim - 1) $25 \mathrm{x} 14,5 \mathrm{x}$ $7 \mathrm{~cm}$;) $27 \times 14 \times 7,5 \mathrm{~cm}$; 22 x 14,5 x $7 \mathrm{~cm}$; w murze wschodnim - 1) 27 x 13,5 x 7,5 cm;2) $25 \times 14 \times 7 \mathrm{~cm}$; 3) $26 \times 13 \times 7,5 \mathrm{~cm}$. Mur zachodni miał szerokość od 55 do $60 \mathrm{~cm}$. W najwęższym miejscu mur wschodni miał szerokość $52 \mathrm{~cm}$, a w najszerszym $57 \mathrm{~cm}$. Odległość między obiema ścianami we wnętrzu, czyli światło korytarza, wynosiła 4 metry.

Ostatni zespół jednostek wiąże się z początkową działalnością na terenie kwartału kościelnego i jest pozostałością po pracach budowlanych wokół kościoła i przykościelnego klasztoru w XIII-XIV w. Poza relacją stratyfikacyjną brakuje wyznaczników do ściślejszego datowania.

Analiza wyników badań z sezonu 2013, a także z lat poprzednich (2008, 2011 i 2012), pozwala stwierdzić, że odsłonięte relikty architektury są pozostałościami przejścia klasztornego. Stanowią je przede wszystkim dwa ceglane fundamenty, położone na warstwie niedużych kamieni z gruzem ceglanym ${ }^{19}$. Korony obu murów zalegały pod ziemią na stosunkowo małej głębokości, średnio od 20 do $30 \mathrm{~cm}$. Każda ze ścian miała po cztery poziomy odsadzek o różnym stopniu wysunięcia, zwiększającym się wraz z kolejnymi, coraz niższymi warstwami. Głębokość posadowienia fundamentów wynosi od 110 do $160 \mathrm{~cm}$ od

${ }^{19}$ A. Cicha, Domy zakonne zamykaja się, s. 78. 
współczesnej powierzchni, przy czym najpłycej położony był mur wschodni ${ }^{20}$. Można także stwierdzić, że fundamenty wykonano $\mathrm{z}$ małą starannością. W niektórych miejscach obrzucone zostały zaprawą, ich lica nie były gładkie, a gdzieniegdzie występowały w nich krzywizny. Łącznie, podczas wszystkich dotychczasowych sezonów badawczych, odsłonięto pięć metrów długości ściany zachodniej i siedem metrów długości ściany wschodniej ${ }^{21}$, w tym w 2013 r. 1,6 metra ściany zachodniej i 2,6 metra ściany wschodniej.

$\mathrm{O}$ istnieniu korytarza łączącego zabudowania klasztorne z prezbiterium kościoła świadczą również zachowane w wykopie $\mathrm{W}-12 / 13$ (oraz wykopach z lat 2008-2012) pozostałości posadzki. O ile podczas prac w poprzednich sezonach odsłonięte zostały wyraźnie widoczne dwa poziomy podłogi, o tyle w wykopie założonym w roku 2013 różnica między nimi była prawie niewidoczna. Wyżej położona, późniejsza posadzka (prawdopodobnie XVIII-wieczna) znajdowała się w stropie 4 warstwy mechanicznej i została zachowana w postaci dużego skupiska cegieł rozbitych na małe fragmenty. Z powodu złego stanu, w jakim się znajdowała, niemożliwe było odczytanie jej układu. Gruzowisko młodszej posadzki częściowo nakładało się na lepiej zachowaną, leżącą bezpośrednio pod nim, pierwszą podłogę z 5 warstwy mechanicznej, zbudowaną z cegieł ułożonych ukośnie względem ścian budowli, w ,jodełkę". Warstwa ta, pochodząca zapewne z przełomu lat 60 . i 70. XVII w., stanowiła pierwotny poziom posadzki, po której zniszczeniu i zapadnięciu się wybudowano kolejną, ceglaną podłogę korytarza klasztornego. Ułożona ona była na warstwie gruzu przemieszanego z zaprawą. Do silnego zniszczenia wyższego poziomu podłogowego z pewnością przyczyniły się prace rozbiórkowe, prowadzone po kasacie zgromadzenia cysterek-benedyktynek w 1834 r. Przy wyburzaniu budynku wyżej położona posadzka została stłuczona, w wyniku czego nawet jej pozostałości przetrwały do czasów współczesnych w niewielkim stopniu. $\mathrm{O}$ wiele lepiej zachowały się relikty starszej podłogi. Jednak układ tego poziomu został również zaburzony, głównie w części środkowej, przez korzenie drzew.

\footnotetext{
${ }^{20}$ Ibid.

${ }^{21}$ Ibid., s. 77.
} 
Jeszcze innym dowodem poświadczającym odkrycie tzw. łącznika klasztornego są bardzo liczne koncentracje gruzu ceglanego z zaprawą. Występowały one w największych ilościach nad posadzką położoną w 4 warstwie mechanicznej. Oznacza to, że po wyburzeniu korytarza w drugiej połowie XIX w. część gruzu użyta została do podniesienia i wyrównania terenu przykościelnego.

\section{Podsumowanie}

Kościół św. Jakuba jest na trwałe wpisany w pejzaż Nowego Miasta Torunia. Przez wiele lat był badany przez specjalistów różnych dziedzin, m.in. historyków, historyków sztuki, archeologów, architektów i konserwatorów zabytków. Poza wspomnianymi opracowaniami archeologicznymi na temat tej monumentalnej budowli powstało wiele prac naukowych, dotyczących nie tylko jej wielowiekowej historii, ale także architektury i wyposażenia wnętrza. Za najbardziej pełne, jak dotąd, opracowanie historyczne dotyczące kościoła należy uznać książkę Liliany Krantz-Domasłowskiej i Jerzego Domasłowskiego ${ }^{22}$. Jej autorzy starają się przedstawić dzieje kościoła od momentu lokacji Nowego Miasta aż po czasy współczesne. Należy jednak zaznaczyć, że w pracy tej nie ujęto wyników badań archeologicznych, które wówczas nie były jeszcze prowadzone wokół kościoła. Jedno z nowszych opracowań na temat kościoła stanowi artykuł Moniki Wierzbickiej ${ }^{23}$. Badaniami nad świątynia zajmowała się również Teresa Mroczkoo ${ }^{24}$. Wymienić też można artykuły Jakuba Adamskiego ${ }^{25}$ czy inne opracowania naukowe dotyczące kościoła ${ }^{26}$.

\footnotetext{
${ }^{22}$ L. Krantz-Domasłowska, J. Domasłowski, Kościót świętego Jakuba w Toruniu .

${ }^{23}$ M. Wierzbicka, Geneza i pierwsza faza budowy kościoła św. Jakuba w Toruniu w pierwszej połowie XIV wieku, Rocznik Toruński, t. 40, 2013, s. 7-35.

${ }^{24}$ T. Mroczko, Architektura gotycka na ziemi chetmińskiej, Warszawa 1980.

${ }^{25}$ J. Adamski, Kilka uwag o architekturze kościoła św. Jakuba w Toruniu, Modus. Prace z historii sztuki, t. VIII-IX, Kraków 2009; tenże, Pseudopoligonalne sklepienie w chórze kościoła pw. św. Jakuba w Toruniu - próba nowego spojrzenia, [w:] Dzieje i skarby kościoła świętojakubskiego w Toruniu.

${ }^{26}$ Dzieje i skarby kościoła świętojakubskiego w Toruniu; Stare i nowe dziedzictwo Torunia; Nowe Miasto Toruń. 750 lat od lokacji.
} 
Historia pobliskiego klasztoru cysterek-benedyktynek pozostawała słabo rozpoznana do 2015 r. Jest to o tyle zaskakujące, że związki toruńskiego konwentu z kościołem św. Jakuba są ewidentne - przez kilkaset lat siostry zakonne sprawowały opiekę nad nim, a także nad pobliskim szpitalem św. Piotra i Pawła. Tę lukę w wiedzy na temat zgromadzenia cysterek-benedyktynek wypełniły badania wykopaliskowe przy kościele i nadzory archeologiczne, prowadzone w latach 2008-2009 podczas remontu budynku dawnego klasztoru. Prace te umożliwiły poznanie szczegółów architektonicznych jedynej zachowanej do czasów współczesnych budowli, wchodzącej w skład zespołu klasztornego. Informacje o niej znalazły się w dwóch artykułach autorstwa Anny Cichej ${ }^{27}$. Duży wkład w poznanie historii konwentu miała również obroniona w 2015 r. (jeszcze nieopublikowana) praca doktorska Anny Cichej pt. „Klasztor przy kościele św. Jakuba w Toruniu w świetle badań archeologiczno-architektonicznych". Z pewnością prace te przyczyniły się do lepszego poznania otoczenia kościoła św. Jakuba.

Elementem, który połączył budynek zgromadzenia z kościołem, był nowożytny korytarz, zwany łącznikiem, wybudowany w drugiej połowie XVII w. Ze względu na klauzurowy charakter miejscowego konwentu miał on służyć lepszej komunikacji między obiema częściami zespołu kościelno-klasztornego. Relikty opisywanego budynku były już odkrywane podczas badań w 2008, 2011 i 2012 r. Jednak dopiero w sezonie 2013 archeolodzy zdołali odsłonić obie ściany korytarza zburzonego w latach 30. XIX w. Pozwoliło to na dokonanie wielu obserwacji istotnych dla dalszych badań wokół kościoła. Dzięki założeniu wykopu W-2/13 możliwe było odnotowanie różnych pomiarów obu murów, głębokości ich posadowienia, określenie wymiarów cegieł oraz szerokości samego korytarza. Przy eksploracji kolejnych warstw mechanicznych odsłonięte zostały dwa poziomy posadzki, z których górna zachowała się w lepszym stanie.

Poza odkryciami reliktów architektury łącznika klasztornego archeolodzy natrafili w wykopie $\mathrm{W}-12 / 13$ na różne kategorie znalezisk ruchomych. Jednymi z ciekawszych były ornamentowane kafle, zloka-

${ }^{27}$ A. Cicha, Klasztor cysterek-benedyktynek przy kościele pw. św. Jakuba w Toruniu; taż, Niełatwe odkrywanie klasztoru toruńskich cysterek-benedyktynek. 
lizowane przy zachodniej ścianie korytarza, na wysokości jej pierwszej i drugiej odsadzki. Poza tym zgromadzono duże ilości masowego materiału zabytkowego w postaci fragmentów ceramiki, zarówno naczyniowej, jak i budowlanej, szkła oraz przedmiotów metalowych. Podsumowując wyniki badań nie sposób pominąć pochówków odkrytych poniżej fundamentów łącznika. Łącznie wydobyto dziewięć grobów zalegających w czterech poziomach, poniżej stopy fundamentowej obu murów łącznika (warstwy 12-15). Najstarszy z nich położony był na głębokości około 49,45 m n.p.m., na poziomie z okresu średniowiecza. Ustalono, że cmentarz w tym miejscu mógł być użytkowany najdłużej do czasu budowy korytarza między kościołem a klasztorem, tzn. do około lat 60. XVII w. Nie ma natomiast pewności co do tego, czy po przejęciu kościoła przez protestantów wszystkie kwatery nekropolii były wykorzystywane równomiernie, czy też używano tylko część z nich. Z pewnością obszar ten służył komunikacji wokół kościoła i w kierunku południowym, można więc przypuszczać, że najwyższy poziom grobowy pochodzi najpóźniej z połowy XVI w., czyli z czasu, gdy zakonnice zajmowały jeszcze budynki klasztorne zanim w $1557 \mathrm{r}$. musiały je opuścić. Jednak, jak dotąd, brakuje archeologicznych dowodów na potwierdzenie tej tezy.

Archeologiczne badania wykopaliskowe przy kościele św. Jakuba, prowadzone od 2008 r., przyniosły wiele cennych informacji o badanym terenie. Dzięki założeniu wykopu W-12/13 bezspornie potwierdzone zostało istnienie tzw. łącznika klasztornego. W 2013 r. po raz pierwszy zaistniała możliwość dokładnego zbadania obu fundamentów ścian tego budynku oraz warstw zalegających pomiędzy nimi. Odkryto również wiele zabytków wzbogacających wiedzę o szeroko pojętej kulturze toruńskich mieszczan żyjących w Nowym Mieście. Dotychczasowe badania archeologiczno-architektoniczne przyczyniły się także do poszerzenia danych archeologicznych na temat architektury kościoła św. Jakuba i historii miasta Torunia. 